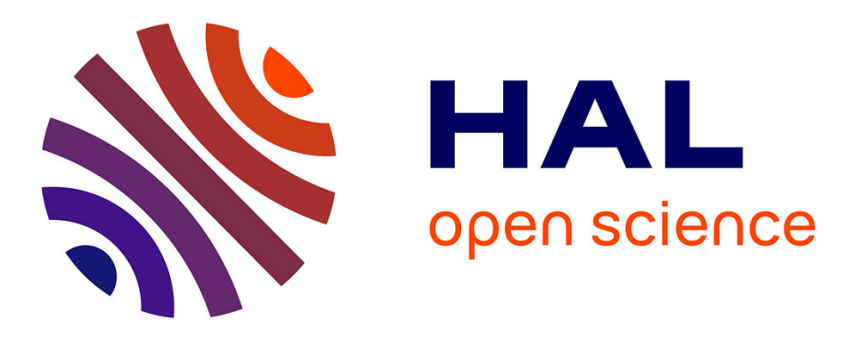

\title{
Future development of apricot blossom blight under climate change in Southern France
}

Paul Tresson, Laurent Brun, Iñaki Garcia de Cortazar-Atauri, Jean-Marc Audergon, Sophie Buléon, Hélène Chenevotot, Freddy Combe, Doriane Dam, Maxime Jacquot, Baptiste Labeyrie, et al.

\section{To cite this version:}

Paul Tresson, Laurent Brun, Iñaki Garcia de Cortazar-Atauri, Jean-Marc Audergon, Sophie Buléon, et al.. Future development of apricot blossom blight under climate change in Southern France. European Journal of Agronomy, 2020, 112, pp.125960. 10.1016/j.eja.2019.125960 . hal-02361185

\section{HAL Id: hal-02361185 \\ https://hal.science/hal-02361185}

Submitted on 15 Nov 2019

HAL is a multi-disciplinary open access archive for the deposit and dissemination of scientific research documents, whether they are published or not. The documents may come from teaching and research institutions in France or abroad, or from public or private research centers.
L'archive ouverte pluridisciplinaire HAL, est destinée au dépôt et à la diffusion de documents scientifiques de niveau recherche, publiés ou non, émanant des établissements d'enseignement et de recherche français ou étrangers, des laboratoires publics ou privés. 


\section{Future development of apricot blossom blight under climate change in Southern France}

\section{2}

3Paul Tresson ${ }^{1,2,7}$, Laurent Brun², Iñaki Garcia de Cortazar-Atauri ${ }^{1}$, Jean-Marc Audergon ${ }^{3}$, 4Sophie Buléon ${ }^{4}$, Hélène Chenevotot ${ }^{2}$, Freddy Combe², Doriane Dam², Maxime Jacquot ${ }^{5}$, 5Baptiste Labeyrie ${ }^{6}$, Vincent Mercier $^{2}$, Claude-Eric Parveaud ${ }^{5}$, Marie Launay ${ }^{1}$

$7^{1}$ INRA US1116 AgroClim, Domaine St. Paul, Site Agroparc, 84914 Avignon Cedex 9, France $8^{2}$ INRA UERI Gotheron, 460 route de Gotheron, 26320 Saint-Marcel-Lès-Valence, France

9³ INRA GAFL, Domaine Saint-Maurice, 67 Allée des Chênes CS60094 84143 MONTFAVET 10CEDEX

$11^{4}$ Chambre d’Agriculture Ardèche et Drôme, 145 Avenue Georges Brassens, 26500 Bourg-lès12Valence

$13^{5}$ GRAB, 460 route de Gotheron, 26320 Saint-Marcel-Lès-Valence, France

14 ${ }^{6}$ SEFRA, Quartier Marcellas - 26800 Etoile Sur Rhône

$15^{7}$ Present affiliations : CIRAD, UR GECO, Montpellier, France ; GECO, Univ. Montpellier, 16CIRAD, Montpellier, France ; LIRMM, Univ. Montpellier, CNRS, France.

17

18

19Corresponding author:

20Marie Launay

21Tel.: +33 4327223 67. E-mail address: marie.launay@inra.fr

22

23Abstract

24

25Climate change will have several consequences for agro-systems, one of which will concern 26changes to the development of pathogens. Because of the losses it causes, particularly in 
27organic farming, Monilinia laxa is an important pathogen affecting apricot crops. This study 28focuses on the consequences of climate change regarding blossom and twig blight (Monilinia 29laxa) of apricot. To achieve this, a Climatic Index of cumulated Blight risk (CIB) was built, to 30obtain the weighted sum of blossom blight incidence throughout the blooming period. An 31epidemiological model to calculate the incidence of blossom blight during every potentially 32infectious episode and based on biological parameters, was calibrated using a trap pot 33experiment where trees were placed in orchards and subject to various meteorological 34conditions. The CIB derived from this model was evaluated on field data, and was shown to 35be a robust and useful tool to predict the effects of climate change on the development of 36apricot blight. Then, using the CIB with a phenological model to predict blooming periods in 37the future, we estimated the risks of apricot blight until 2100 on four contrasted apricot 38cultivars and in three geographical zones under climate change scenarios RCP 4.5 and 8.5. 39This study revealed different effects of climate change depending on the cultivar and altitude. 40Apricot trees would bloom earlier (up to a difference of 50 days between 1950 and 2100) 4lunder climate change. Under the combined effects of these shifts of blooming period and 42changing climatic conditions, late cultivars such as Bergarouge might see a reduction in the 43risk of blossom blight (down to 31\%) because of warmer but dryer blooming periods. Other 44varieties (e.g.: Bergeron) could experience an increase in this risk by up to $27 \%$ with a shift of 45the blooming period towards rainier conditions at the highest altitudes. The results of this 46study could be used to anticipate future changes as well as be used at present as a decision47support tool for farmers.

\section{8}

\section{Key words}

50Blossom blight, Monilinia laxa, apricot orchards, Prunus armeniaca L., climate change, 51modelling, phenology 


\section{Introduction}

54

55

56Climatic changes such as increase of air temperature and rainfall variability can directly 57 and/or indirectly affect pathogens and the plant diseases they are causing, which has been 58recently reviewed (Trebicki and Finlay, 2019). All important life cycle stages of fungal 59pathogens are more or less directly influenced by the prevailing environmental conditions. 60The infection process is particularly dependent on the species specific temperature and 61humidity requirements of the pathogens. According to the review article by Juroszek and 62Tiedemann (2015) infection risk is the most frequently investigated plant disease parameter in 63disease risk simulation studies, where crop disease models have been linked to climate 64scenarios including, for example, downy mildew infection risk of grapevine (Vitis vinifera L.) 65published by Launay et al. (2014). As well as direct effects on pathogens, climate change will 66also affect plant phenology (Körner and Basler, 2010) and thus modify host-pathogen 67synchronism (Caubel et al., 2017). This indirect effect of climate change on disease 68development will be all the more crucial regarding pathogens that infect plants during a short 69and sensitive phenological stage, such as infectious diseases which attack during blooming 70periods.

71Apricot (Prunus armeniaca L.) is an important crop in the Mediterranean region (14,000 ha 72planted and 180,000 T of fruit produced in 2014) and particularly in southern France (third 73most important fruit crop) (Lichou and Jay, 2012), but like other such crops, apricot requires 74repeated fungicide treatments to secure production. In 2012, an average apricot orchard in 75France received 11.8 treatments, including 8.1 against fungi (AGRESTE, 2014). Among the 76different fungi that affect apricot, Monilinia spp. causes the most losses (Hrustić et al., 2012; 
77Oliveira Lino et al., 2016). Three species of Monilinia have a significant economic impact: 78Monilinia laxa, Monilinia fructicola and Monilinia fructigena (Hrustić et al., 2012; Oliveira 79Lino et al., 2016). The latter has been the subject of the most study because of the damages it 80also causes to apple and pear crops. However, infections affecting stone fruits are mainly due 81to Monilinia laxa and Monilinia fructicola (Oliveira Lino et al., 2016). Monilinia laxa can 82infect apricot blossom, twigs and fruit. Blossom and twig blight are the principal concerns, 83particularly for organic farmers, and can cause losses of up to $90 \%$ in Southern France 84(Parveau et al., 2016).

85Apricot blossom is sensitive to blight (whether this is caused by M. laxa or M. fructicola) at 86flowering. The flowers have been shown to be the most susceptible when they are wide open 87(BBCH Stage 65; Hack et al., 1992) (Luo et al., 2001). In some cases, infected blossoms can 88then convey infection to the twigs, generating a necrosis of internal tissues. Moreover, twig 89blight can only be caused when transmitted via infected blossom (Agrios, 2005). During the 90present study, we focused on twig and blossom blight, as there is a causal relationship 91between the two, and did not address the problem of fruit rot.

92The development of Monilinia fungal infection on stone fruit blossom is linked to 93meteorological conditions in several ways, as has been demonstrated by previous studies. 94Experimenting in a growth chamber, Tamm et al. (1995) revealed the effects of the duration of 95petal wetness and temperature on the development of blossom blight caused by M. laxa on 96cherry (Prunus avium L.). Luo et al., (2001) produced similar results in 2001 in their study on 97plums (Prunus domestica L.) infected by M. fructicola. Relative humidity and water activity 98have also been shown to affect the development of $M$. fructicola on cherry blossom petals 99(Koball et al., 1997). Casals et al., (2010) highlighted the importance of the same weather 100 factors to the germination of $M$. fructicola on Petri dishes (Casals et al., 2010). However, 101although the effects of climate on the development of Monilinia have been studied before, to 
102our knowledge this has only been done under controlled conditions. It may be difficult to 103ensure reliable recordings of the variables used to describe incidence, mycelial development 104or conidia germination in the field. For example, leaf wetness duration is widely used in crop105disease epidemiological models but remains difficult to measure accurately (Gleason et al., 1062008).

107In the context of climate change, the increasing threat of apricot blight makes it necessary to 108develop tools that will enable us to define/imagine crop systems adapted to future conditions. 109There is therefore a need for bioclimatic modelling to anticipate the changes to come and 110adapt our agro-systems (Jeschke and Strayer, 2008). Current epidemiological models that are 111used as Decision Support Systems (DSS) are often of a purely statistical nature. They are 112calibrated on current data for use at present but may lack robustness regarding any changes to 113conditions which fall outside their domain of validity. On the other hand, bioclimatic and 114physiological models are calibrated under controlled conditions (Petri dishes, growth 115chambers, greenhouses) that may not reflect the reality in the field, so are once again 116deficient. Faced with the future uncertainties inherent in climate change, our models need to 117be adaptable and valid under different conditions (Maier et al., 2016).

118The study we present here only concerned M. laxa, as several identification tests performed 119during the experiments based on the Lane identification key (Lane, 2002) had reported a great 120majority of $M$. laxa cases (93.7\%), rather than $M$. fructicola (6.3\%) and M. fructigena (none).

\section{1}

122The aims of this study were to (1) produce a climatic index of blight risk thanks to an 123epidemiological model simulating the incidence of blossom and twig blight caused by $M$. 124laxa on apricot. This model, including biological parameters, was calibrated on field data 125 from a trap pot experiment and then evaluated on independent data from a network of 126orchards; 
127(2) determine the effects of climate change on apricot blossom blight. To do so, we first of all 128applied a phenological process-based model to simulate flowering changes, and then 129implemented our epidemiological model to calculate the incidence of blossom blight on four 130contrasted apricot cultivars in three geographical ranges and under two climate change 131scenarios.

132

\section{Materials and methods}

\subsection{Building a climatic index of cumulated blight risk}

136The Climatic Index of cumulated Blight risk (CIB) that we propose is built in several sections. 137A blossom incidence $I$ is calculated using a modified version of the epidemiological model 138proposed by Tamm et al. in 1995. This factor reflects primary blossom infection due to 139inoculum dispersal and infection as a function of rainfall and temperature. This blossom 140infection can then be transmitted to twigs. This transmission is not equal at all stages of 141blossom development so incidence $I$ is weighted according to the proportion of disease142sensitive stages at the time of infection, to form a Weighted Incidence WI. The twig blight 143observed at the end of blooming is thus the result of several infectious episodes and the 144different WI experienced by an orchard are then summed to obtain a Climatic Index of 145cumulated Blight risk (CIB) that reflects twig infection.

146

\subsubsection{Incidence of blossom blight}

148The epidemiological model we used for this study was a modified version of that proposed by 149Tamm et al., (1995) to describe the incidence of $M$. laxa blossom blight (number of 150symptomatic blossoms/total number of blossoms) on sour cherry trees (Tamm et al., 1995). 151This model describes a continuous response surface for any given temperature and wetness 
152duration, making it usable under different conditions and appropriate for the study of climate 153change. We nevertheless made several modifications to this model.

154First, Tamm's model takes wetness duration and temperature as input variables to generate 155incidence data. During our study, we preferred to use rainfall rather than wetness duration to 156explain blight incidence (see Supplementary Materials 1 for a comparison between wetness 157duration and rainfall). One of the advantages of this approach is that rainfall data are easier to 158measure accurately in the field.

159Second, in order to prevent the model from generating positive incidence values in the 160absence of rainfall (as the trees displayed no symptoms under dry conditions), we added a 161corrective term taking a zero-value for null rainfall and a one-value otherwise. In this context, 162a supplementary factor built on precipitation $(p)$ and a constant $\varepsilon, p /(p+\varepsilon)$ with $\varepsilon \neq 0$, was 163added to force the model to return no incidence if the rainfall is null.

164The equation of our modified version of the Tamm model is therefore as follows (eq.1): 165

$166 I(p, T)=\frac{p}{p+\varepsilon} * i_{\text {max }} *\left\{1-\left(1-i_{0}(T)^{\mid 1-m)}\right) * e^{-r(T) * p}\right\}^{\frac{1}{1-m}}(1)$

167with,

$168 i_{0}(T)=\gamma_{1} * \phi^{\gamma_{2}} *(1-\phi)$

$169 r(T)=\rho_{1} * \phi^{\rho_{2}} *(1-\phi)$

170where,

$171 \phi=\frac{\left(T-T_{\min }\right)}{\left(T_{\max }-T_{\min }\right)}$

173The model returns the incidence $I$ for a given rainfall $p$ and temperature $T$. The model takes as 174known parameters $i_{\max }$ (the maximum observed incidence), and $T_{\min }$ and $T_{\max }$ the minimal and 175maximal cardinal temperatures for $M$. laxa development. The fit parameters $\rho_{1}, \rho_{2}, \gamma_{1}, \gamma_{2}$ and $\varepsilon$ 
176were estimated during model fitting. The shape parameter $m$ was set at 0.9 as advised by 177Tamm (Tamm et al., 1995). The $\phi$ factor describes a "bell curve” response to temperature. The $178 i_{0}(T)$ factor was originally designed to return an incidence in the absence of wetness duration. 179We retained it despite the supplementary factor that we added because we saw a rapid 180increase in the incidence observed on trees under low rainfall levels. This factor therefore 181describes incidence at low rainfall values. The $r(T)$ factor is a rate parameter describing the 182response to rainfall.

183

184In addition to this model, we also tested two others (see Supplementary Materials 2.): (i) a 185simple generic infection model based on epidemiological knowledge and proposed by 186Magarey and colleagues (Magarey et al., 2005, referred to below as “Magarey”), and (ii) a 187purely statistical model (linear regression, referred to as "LM") established from our trap pot 188experiment dataset. We chose the modified Tamm model we because of its greater robustness 189and suitability for climate change studies (for details see Supplementary Materials 2.).

192As the proportion of disease-sensitive blossoms is evolving with phenology, $I$ has to be 193weighted for rainy events that occur at different times during blooming.

194Different blooming stages are susceptible in different ways to blossom blight (Luo et al., 1952001). We observed that 58 to $65 \mathrm{BBCH}$ stages (flower opening) displayed comparable 196sensitivity and the 57 stage (sepals opening) had less sensitivity; 57 stage infections were only 197possible in the context of a highly infectious event and were observed at lower proportions 198(data not shown). The Weighted Incidence WI was thus defined as:

$200 W I=\frac{I \times\left(0,25 S_{57}+S_{5865}\right)}{S_{57}+S_{5865}}$ if $I \geq 0,5$ 
$201 W I=\frac{I \times S_{5865}}{S_{57}+S_{5865}}$ if $\mathrm{R}<0,5$

202With $\mathrm{S}_{57}$ being the number of flowers at BBCH stage 57 and $\mathrm{S}_{5865}$ being the number of flowers 203at BBCH stages 58 to 65 .

204Because twig infection is caused by infected blossoms, use of these weightings was necessary 205to correctly describe transmission of the infection to twigs.

206

207

\subsubsection{Climatic index of cumulated blight risk}

208The twig infection observed was the result of several blossom infections, each being caused 209by a rainy event during blooming. We chose to identify a single rainy event during the 210blooming period as a record of rainfall separated from another rainfall episode by at least 4 211 hours without rain or leaf wetness. We estimated that 4 hours was sufficiently long for the 212wetness caused by the rain to dry, so that the next event could be considered separately. 213Finally, by summing the WI associated with different rainy events, we were able to build a 214Climatic Index of cumulated Blight risk (CIB) reflecting the history of infectious events 215(eq. 7).

$216 C I B=\sum_{i=1}^{n} W I_{i} \quad$ (7) $n$ being the number of recorded rainy events

218 2.2. Data

219

220

2.2.1. Trap pot experiment for model calibration

221CIB parameters corresponding to those enabling calculation of the blossom infection $(I)$ 222component were optimised with data from a trap pot experiment. This trap pot experiment 223was performed under semi-controlled conditions: we chose the weather events to which the 224pots would be exposed by taking them out into the orchard or returning them to the 
225greenhouse. In the orchard, they continued to be exposed to field inoculums and current 226weather conditions. The fact that we could choose the events to which the trees were exposed 227enabled us to cover a broad range of weather conditions for model calibration, and at the same 228time this contributed robustness to our model as the calibration was performed using field 229data.

230The trap pot experiment for model calibration was carried out at the INRA Gotheron Research 231Station (Southern France, 44 58’ 37’' N, 4 55’ 48’' E) over a two-year period, i.e. 2017 and 2322018.

233Trap apricot trees in pots were set out in the orchard for a defined period of time (around 24 234hours), during which they were exposed to recorded meteorological conditions (see 3.1.2) and 235outdoor Monilinia inoculum. The pots were then moved to a greenhouse in which the 236conditions were controlled and favourable to the expression of blossom blight.

237Apricot trees of the Bergarouge cultivar (Bergarouge ${ }^{\circledR}$ (A2914) Avirine (cov)) were used as 238the trap pot trees. This cultivar is known to be very sensitive to blossom blight (Parveau et al., 2392016). The expression of symptoms in the event of exposure to $M$. laxa and favourable 240climatic conditions for infection was therefore ensured. The orchard comprised three lines of 24125 trees along a south-north axis.

242We used seven groups of six Bergarouge trees in pots during 2017 and nine groups of five 243trees in 2018. Before exposure, the trees were maintained in a cold room $\left(4^{\circ} \mathrm{C}\right)$ to keep their 244phenology under control. Each tree within a group was exposed for the same period in the 245orchard between the BBCH 57 and $\mathrm{BBCH} 65$ stages (disease-sensitive stages) and during the 246blooming period of the Bergeval orchard. The first group of trees was exposed on 27 February 247and the last on 10 March in 2017, while in 2018 the trees were exposed for periods between 7 248and 28 March. After exposure, pots were placed in a greenhouse under controlled conditions 249 (relative humidity $>40 \%$, ambient temperature between $5^{\circ} \mathrm{C}$ and $25^{\circ} \mathrm{C}$ ). 
250With each group, a control tree was left in the greenhouse to prove the absence of any 251 inoculum inside the greenhouse.

252

253

\subsubsection{Orchard network for model evaluation}

254The model was tested on independent data by studying an orchard network in Southern 255France. The CIB was calculated for the orchards and compared versus a measured Twig 256Blight Incidence (TBI).

257

258The network comprised 15 orchards located in the Drôme and Ardèche regions (Rhône Valley, 259France, ranging between 448'29’'E - 458’54’ $\mathrm{E}$ and between $\left.45^{\circ} 14^{\prime} 52^{\prime \prime} \mathrm{N}-44^{\circ} 41^{\prime} 51^{\prime \prime} \mathrm{N}\right)$. 260Thirteen orchards were studied in both 2017 and 2018 and two were studied in 2018, thus 261providing a total of 28 siteXyear measurements of Twig Blight Incidence. None of the 262orchards was treated against fungal diseases.

263These 15 orchards were planted with two moderately sensitive cultivars: ten with the 264Bergeron cultivar (Bergeron (660)) and five with the Bergeval cultivar (Parveau et al., 2016). 265These cultivars are less sensitive to blossom blight than the Bergarouge trees used for the 266blossom blight model. However, this was not expected to alter the performance of the model 267(see Discussion).

268

269Blighted twigs were counted on five random main branches per orchard to obtain one TBI 270notation per orchard:

$271 T B I=\frac{\text { numberofblightedtwigs }}{\text { totalnumberoftwigs }}$

272

273The evolution of blossom phenological stages was recorded regularly (three times a week) on 274ten trees in each orchard. On several occasions, the proportion of blossom at each stage was 
275estimated. The proportion of blossom at any time during the different stages was then 276extrapolated linearly between two estimation dates.

277

278

\subsubsection{Recorded meteorological data}

279A weather station (IMT 200 Pessl Instruments, Weiz, Austria) was placed in the middle of 280each orchard (trap pot experiment and each orchard in the orchard network) at a height of 1.80 281m. Rainfall (mm), temperature $\left({ }^{\circ} \mathrm{C}\right)$ and leaf wetness (min) were recorded at an hourly time 282step using a rain gauge, temperature sensor and filter paper leaf sensor, respectively. Leaf 283wetness was also measured with an electric resistance sensor to assess the reliability of the 284measurements (this variable is used in Supplementary Materials 1).

285

286

\subsubsection{Future climate data}

287We performed the study using the predicted rainfall and temperature data of 46 DRIAS grids 288(French climate change modelling project, http://www.drias-climat.fr), which are $8 \times 8 \mathrm{~km}$ 289wide. They were selected in the Rhône Valley at locations were apricot is currently being 290cultivated.

291

292For more clarity we decided to group the DRIAS grids thus employed in several clusters. A 293Hierarchical Ascending Classification was performed (mean temperature and mean rainfall as 294entry variables) and reflected groups as a function of altitude (see Supplementary Materials 2953). The following clusters were thus used (see Fig. 1):

296Cluster 1: altitude $<100 \mathrm{~m}$

297Cluster 2: $100 \mathrm{~m} \leq$ altitude $\leq 400 \mathrm{~m}$

298Cluster 3: altitude $>400 \mathrm{~m}$

299 
300Present and future climatic conditions (between 1950 and 2100) were applied using the 301ALADIN-Climate regional climate model nested within the global ARPEGE model (Deque, 3022010). Three periods were simulated: the 'recent past' (RP, 1970-1999), 'near future' (NF, 3032020-2049) and 'far future' (FF, 2070-2099) according to two 'representative concentration 304pathway' emission scenarios, RCP4.5 (median) and RCP8.5 (pessimistic) (Pachauri et al., 3052014).

306

307 2.3. Application to climate change

308

309

\subsubsection{Phenological model}

310In order to apply our model to the context of climate change, it was necessary to forecast 31 lapricot blooming periods in the future. We therefore implemented a two-step phenological 312 model on future climatic data.

313

314 2.3.1.1. Estimation of the mid-blooming date

315To simulate the blooming period for apricot we used the sequential phenological process316based model proposed by Andreini et al. (2014). The date of budbreak is simulated using the 317Smoothed Utah function (Bonhomme et al., 2010, advised by Andreini et al. 2014) and the 318time between budbreak and mid-blooming (F50) is simulated with a sigmoid model (Chuine 319et al., 2016). We estimated the mid-blooming dates for four cultivars chosen to have different 320precocities in terms of dormancy release and blooming: cv. Beliana (Beliana ${ }^{\circledR}$ Sayeb) 321(median to early blooming period), cv. Bergarouge (used during the trap pot experiment, 322median blooming period), cv. Bergeron (late blooming period, widely used in the Rhône 323Valley) and cv. Rouge du Roussillon (Rouge du Roussillon (A157)) (early blooming period). 
324The models we used to estimate the F50 date had already been calibrated for the different 325cultivars (Andreini et al., 2014, Chuine et al., 2016), (Garcia de Cortazar-Atauri et al., 2013). 326

327

\subsubsection{Estimation of the blooming period}

328The expand of the blooming period was estimated by studying the phenological data recorded 329by the orchard network. No significant differences were found between the expands of the 330blooming periods of Bergeron and Bergeval (T-test, p-value $=0.2196)$. Recordings on the two 331 cultivars were then grouped. We found that the proportion of disease sensitive stages during 332blooming (degree-days) could be approximated using a Gaussian curve centred on the 333maximum proportion of opened flowers (around 100\% of opened flowers) and of a 28 degree334day standard deviation. It was then possible to estimate the expand of the blooming period at 335around F50, starting 122 degree-days before F50 and ending 133 degree-days after F50. 336

337

\subsection{Data analysis}

338Statistical analysis and computations were performed using $\mathrm{R}$ 3.4.3. Computations for 339phenological modelling were performed using Phenology-Modeling-Platform 5.5 340(http://www.cefe.cnrs.fr/fr/recherche/ef/forecast/phenology-modelling-platform) (Chuine et 341al., 2013).

342

343 2.4.1. Model calibration

344Goodness-of-fit was assessed using the Root Mean Square Error (RMSE, eq.9) and Relative 345Root Mean Square Error (RRMSE, eq.10).

346

$347_{R M S E}=\sqrt{\frac{\sum\left(S_{i}-O_{i}\right)^{2}}{n}}$ (9) and $\quad R R M S E=\frac{R M S E}{\bar{O}}$ 
349Where $n$ is the number of observations, $S_{i}$ the simulated value and $\bar{O}$ the average of observed 350values $O_{i}$. RMSE can be broken down into two components representing systematic (bias or 351RMSEs) and unsystematic (dispersion or RMSEu) error (Willmott, 1981).

352

$353_{R M S E S}=\sqrt{\frac{\sum\left(\hat{S}_{i}-O_{i}\right)^{2}}{n}}$

$354_{R M S E u}=\sqrt{\frac{\sum\left(\hat{S}_{i}-S_{i}\right)^{2}}{n}}$

355

356With $\hat{S}_{i}$ being derived from the linear regression of observed versus simulated values: $357 \hat{S}_{i}=a+b * O_{i}$ with $a$ and $b$ being the parameters of the regression.

360The performance of our model was then assessed from the correlation between the observed 361Twig Blight Incidence of orchards in the network and their respective calculated CIB. 362

363

\subsubsection{Algorithm for climate change study}

364The method used for computation is described in Figure 2.

365

3663. Results

367

368

\subsection{Model fitting and evaluation}

369Our model revealed a RMSE of 6.12\% incidence when comparing the simulated incidence on 370flowers with those observed in the calibration dataset. Given that the average incidence was $37127.34 \%$, the RRMSE of our model was $22.43 \%$, which could be considered to be a 
372satisfactory performance. A comparison between simulated and observed incidences is 373illustrated in Figure 3.

376Furthermore, the RMSEs was 1.86\% whereas the RMSEu was 5.84\%, meaning that the error 377 was mostly due to dispersal of the points (i.e. biological variability) and not to bias in the 378chosen formalism. This can also be seen in Figure 4 which represents the residuals associated 379with each point.

380

381The parameter values we obtained after optimisation are shown in Table 1.

382

383The CIB calculated using our model was correlated with Twig Blight Infection at $\mathrm{R}^{2}=0.46$ 384(Fig.5). Given the numerous parameters varying between the orchards (see Discussion), we 385considered this performance to be satisfactory.

386

387 3.2. Evolution of blooming dates

388The predictions of the phenological model indicated a shift of all mid-blooming dates to an 389earlier day in the year (DOY) for all cultivar and clusters. Under climate change scenario 390RCP4.5, the median blooming date was 20 days earlier, from 89.9 DOY (i.e. 31 March in 3911950) to 72.2 DOY (March 12 in 2100). This shift was more marked under scenario RCP8.5, 392 where the F50 date moved to 61.5 DOY (1 $1^{\text {st }}$ March) in 2100 (Fig. 6). Rouge du Roussillon and 393Beliana displayed similar but moderated shifts toward earlier blooming dates (of around 20 394days), but the Bergeron cultivar notably experienced a shift of almost 50 days in its mid395blooming date in all clusters under the RCP8.5 scenario. Therefore, by 2100, the differences 396in blooming periods between Bergeron and other cultivars would no longer be significant. On 
397the contrary, Bergarouge experienced less variation in its blooming date and would thus 398become the latest blooming cultivar by 2100 in both cluster 1 and cluster 2 . We concluded 399that under the RCP4.5 and RCP8.5 scenarios, but particularly with the latter, a shift towards 400earlier blooming periods and a convergence between the blooming periods of different 401cultivars would be observed, with consequences regarding the climatic conditions during 402blooming and thus the risk of blossom blight.

403

$404 \quad$ 3.3. Evolution of climatic conditions during the blooming period

405This future convergence of blooming periods caused a convergence of the climatic conditions 406prevailing during the blooming of different cultivars. In particular, Bergeron and Bergarouge 407experienced opposite and strong shifts. The blooming conditions for Bergarouge shifted 408towards warmer but dryer conditions, and would be $2{ }^{\circ} \mathrm{C}$ warmer in the far future than in the 409past in all clusters and under both scenarios, the trees receiving 10 to $20 \mathrm{~mm}$ less rainfall 410during blooming (Fig. 7). On the other hand, Bergeron saw a marked shift of its blooming 411period towards earlier dates, so that this cultivar would experience cultivar conditions that 412 would be colder $\left(2.8^{\circ} \mathrm{C}\right.$ lower in cluster 3 and RCP8.5) and rainier (especially in cluster 1$)$. 413Rouge du Roussillon and Beliana saw more moderate shifts; those in cluster 3 shifted towards 414dryer conditions while cluster 1 saw a temperature-related shift towards warmer conditions.

415

416From an epidemiological standpoint, the impacts of these changes to climatic conditions 417during blooming could indeed be assessed by the CIB computation.

418

$419 \quad$ 3.4. Future risk of apricot blight

420Significant differences in future CIB were only found in the eventuality of the RCP8.5 421 scenario, so this is the only one described in greater detail below. 
422The CIB calculated by the model revealed different consequences of climate change that 423varied according to the clusters and cultivars studied (Fig.8). Variations in the CIB between 424past and far future ranged from $+27 \%$ (Bergeron cluster 1) to $-31 \%$ (Bergarouge, cluster 1). 425However, cluster 1 (lowest altitudes) displayed greater inter-annual variations, although these 426differences were not always significant.

427

428We noted a significant in the risk to which Bergarouge is exposed, in all clusters. This could 429be linked to the shift of its blooming period to warmer but dryer conditions, the expected 430positive effect from rising temperatures being counter-balanced by the negative effect of 431lower rainfall (Fig. 7). On the other hand, an increase in risk may be possible in the near 432future (nf) for Bergeron in cluster 3 (altitudes higher than $400 \mathrm{~m}$ ) because of colder but rainier 433blooming conditions. Beliana and Rouge du Roussillon experienced more diverse conditions 434depending on the cluster, with a general trend regarding disease risk that stagnated or 435diminished in the far future.

436

\section{Discussion}

438This study generated a climatic index of cumulated blight risk based on an epidemiological 439model, describing the blossom and twig blight caused by M. laxa on apricot. The model we 440used was built using biological parameters driving development of the fungus (optimal 441 growth temperatures, response to rain). This gave the model robustness, enabling its use 442within the framework of a changing climate. Furthermore, by comparison to the original 443Tamm model, this model was calibrated and evaluated on easily measurable variables and in 444the field, so that it is more applicable and closer to observed incidence. To our knowledge, 445this approach - integrating the incidence of both blossom and twig blight in the same CIB 
446index, based on biological parameters and easily accessible weather inputs (daily temperature 447and rainfall), and valuable under field conditions - is entirely new.

448To estimate the effects of climate change on blight risks, we first of all determined the 449sensitivity periods of several cultivars. By estimating the present and future CIB at different 450altitudes (and even latitudes to a lesser extent), we were able to reveal different changes as a 451function of the precocities of the trees and their altitudes. The late blooming cultivar Bergeron 452might bloom earlier and face rainier conditions, leading to an increase in the incidence of twig 453blight; on the other hand, the median cultivar Bergarouge might shift towards later blooming 454and dryer conditions, accompanied by a lower blight incidence at all altitudes.

455

$456 \quad$ 4.1. Variabilities affecting evaluation

457The results of evaluating this model using data from the orchard network could be considered 458as satisfactory $\left(\mathrm{R}^{2}=0.44\right)$. Indeed, numerous parameters varied between orchards in the 459network. For example, the amount of Monilinia inoculum could vary at the landscape or 460regional levels. Furthermore, the fitting performances of the epidemiological model 461 $($ RRMSE $=0.22)$ were equal to or better than the fitting performances regarded as satisfactory 462by recent comparable studies (e.g.: Gouache et al., 2015; Morales et al., 2018).

463We set blossom-twig transmission according to our empirical observations. However, 464variations in twig infection via blossom could impact the performance of the model. For 465instance, blossom-twig transmission could also depend on climatic conditions. A large part of 466the correlation between the calculated CIB and observed TBI was due to the choice of 467weightings. More observations might help to improve our understanding of blossom-twig 468transmission. For example, orchards that experienced rain at the end of the blooming period 469displayed greater sensitivity to twig blight infection. This factor could be determined by 470means of other trap pot experiments or the analysis of a larger orchard network experiencing a 
471variety of conditions, with a broader range of latitudes; for example, combining 472Mediterranean and more continental climatic conditions.

473The biological construction of our epidemiological model means that it could be used to 474address future conditions at a single location (in the present case, the Rhône Valley) but 475should also make the model usable at various geographical locations. For example, testing our 476model in other apricot growing regions such as Spain or Turkey would further assess the 477robustness of the model we propose here.

478It should be noted that the model used to calculate blossom blight infection was calibrated on 479Bergarouge trees, which are more sensitive to blossom blight than Bergeval and Bergeron 480(Parveau et al., 2016). However, because Bergeron and Bergeval display comparable 481sensitivity (and thus comparable differences in sensitivity versus Bergarouge), the correlation 482between CIB and TBI should not be affected mathematically by a difference in sensitivity 483between Bergarouge and Bergeron or Bergeval.

\section{4}

\section{4.2. Working hypotheses}

486We only studied climate-related factors during this study, in order to assess changes to the 487infection risk in line with climate change. Nevertheless, factors of a genetic (e.g. resistance), 488physiological (e.g. water stress) or epidemiological (e.g. inoculum repartition) nature should 489also be taken into account.

490Here, the apricot cultivars were only compared through the lens of precocities, but a factor 491reflecting varietal sensitivity could be added. Such study would enable assessment of the 492respective roles of phenology and genetics: is it better for a tree to avoid blight or resist it? 493As for physiological factors, two types of interactions have been documented to date: "cross494protection" for plants whose resistance to biotic stresses is increased by the onset of abiotic 495stress, and "cross-vulnerability" for plants whose susceptibility to biotic stress is increased 
496under abiotic stress (Fones and Gurr, 2017). These processes might modify the host response 497to increased biotic and abiotic stresses under climate change, and should therefore be 498considered under a more integrative modelling approach.

499Further, inoculum levels may vary at a landscape or regional level. For example, they may be 500affected by the provenance of air masses, as has already been shown for Botrytis cinerea 501(Leyronas and Nicot, 2013). Moreover, amounts of primary inoculum may also vary as a 502function of previous disease levels or orchard management practices (Lichou and Jay, 2012).

503The Monilinia inoculum may differ in terms of both quantity and quality involving a change 504to the predominant Monilinia species. For instance, because it is better suited to warmer 505temperatures (Casals et al., 2010) and displays pesticide resistance (Lichou and Jay, 2012), 506Monilinia fructicola may become more important than Monilinia laxa in the European 507inoculum landscape as climate change progresses. In addition, the sexual reproduction of 508Monilinia laxa has not yet been observed under natural conditions in Europe (Hrustić et al., 5092012) but warmer temperatures could trigger this development cycle (Agrios, 2005). Such a 510change would render obsolete the model we present here, as this aspect of development 511remains a limiting factor. These features could also affect epidemiological concerns over the 512coming decades. Epidemiological studies on M. fructicola under semi-controlled conditions 513 would then be of value in the context of future research.

\section{4}

\section{4.3. Uncertainty of climatic variables}

516Variations affecting the risk predicted by the model were mainly due to rainfall. However, this 517variable is hard to predict in climate change scenarios, and climatic models can generate 518markedly different predictions (Jouzel et al., 2014). For instance, the DRIAS data we used are 519based on the ALADIN model proposed by the French National Weather Research Centre 520(Centre National de Recherches Météorologiques) and used to forecast weather in the context 
521of climate change; it predicts an overall reduction of rainfall in France between [1976-2005]

522and [2071-2100] under the RCP8.5 scenario in summer (-0.38 mm.day $\left.{ }^{-1}\right)$. On the other hand, 523the WRF (Weather Research and Forecasting) model proposed by the US National Center for 524Atmospheric Research predicts an overall increase of rainfall of the same scope $(+0.32$ 525mm.day ${ }^{-1}$ ) (Jouzel et al., 2014), hence the uncertainty attached to ongoing modelling 526approaches used to study future impacts of climate change.

\section{7}

\section{Conclusion}

529The Climatic Index of cumulated Blight risk we propose here offers an efficient reflection of 530twig blight infection calculated from the weighted sum of blossom blight infection episodes $531\left(R^{2}=0.44\right.$ with independent evaluation). Blossom blight infections were estimated with a 532good fit to an epidemiological model (RRMSE $=0.22$, largely due to unsystematic error). 533This model, calibrated and evaluated on field data (using easily measurable variables such as 534rainfall) and based on biological parameters, was shown to be a robust and useful tool to 535predict the consequences of climate change regarding the development of apricot blight. 536Because of a shift of the blooming period, the Bergarouge apricot cultivar could experience a 537long term reduction in the climatic risk to which it is exposed (in the far future). By contrast, 538cultivars such as Beliana or Bergeron could see a medium-term (near future) increase of this 539risk of blossom blight at altitudes above $100 \mathrm{~m}$. The various conditions under which our 540model can be employed means that it could be applied to conditions other than those in the 541Rhône Valley, and possibly worldwide.

542

\section{Acknowledgements}

544This study was funded by the GIS Fruits Network, FAN de Bio and FEADER ClimArbo 545projects. The authors gratefully acknowledge the assistance received from Emilie Freyssinet 
546and William Chambeyron during field and lab work. The authors are also grateful to Benoît 547Saunier and Tom Fillot for their careful reviews of the paper.

548

\section{References}

550

551AGRESTE, 2014. Enquête pratiques phytosanitaires en arboriculture 2012.

552

553Agrios, G., 2005. Plant Pathology, 5th Edition. ed. ELSEVIER.

554

555

556

557Andreini, L., de Cortázar-Atauri, I.G., Chuine, I., Viti, R., Bartolini, S., Ruiz, D., Campoy, 558J.A., Legave, J.M., Audergon, J.-M., Bertuzzi, P., 2014. Understanding dormancy release in 559apricot flower buds (Prunus armeniaca L.) using several process-based phenological models. 560Agricultural and $\quad$ Forest $\quad$ Meteorology $210-219$. 561https://doi.org/10.1016/j.agrformet.2013.10.005

562

563

564

565

566

567Bonhomme, M., Rageau, R. et Lacointe, A., 2010. Optimization of endodormancy release 568models, using series of endodormancy release data collected in France. Acta Hortic. 2010. 569Vol. 872, pp. 51-60. https://doi.org/10.17660/ActaHortic.2010.872.4

570 
571Casals, C., Viñas, I., Torres, R., Griera, C., Usall, J., 2010. Effect of temperature and water 572activity on in vitro germination of Monilinia spp.: Effect of temperature and water activity on 573Monilinia spp. Journal of Applied Microbiology 108, 47-54. https://doi.org/10.1111/j.13655742672.2009.04402.x

575

576

577

578Chuine, I., Garcia de Cortazar-Atauri, I., Kramer, k., Hänninen, H., 2013. Plant Development 579Models, in: Phenology: An Integrative Environnemental Science. Springer, Dordrechts, 580Netherlands, pp. 275-293.

581

582Chuine, I. Bonhomme, M., legave,J-M., Garcia de Cortazar-Atauri, I., Charrier, G., Lacointe, 583A., Améglio, T., 2016. Can phenological models predict tree phenology accurately in the 584future? The unrevealed hurdle of endodormancy break. Global Change Biology 22, 34445853460.

586

587Deque, M., 2010. Regional climate simulation with a mosaic of RCMs. Meteorol. Z. 19, 588259-266.

589

590

591

592Fones, H.N., Gurr, S.J., 2017. NO(X)ious gases and the unpredictability of emerging plant 593pathogens under climate change. BMC Biol. 15.

594 
595Garcia de Cortazar-Atauri, I., Bertuzzi, P., Andreini, L., Madon, F., Audergon, J-M., 2013.

596Adaptation de l'abricotier aux changements climatiques : Estimation des risques génétiques et 597géographiques liés aux avortements floraux et à l'époque de floraison. Le réseau 598agroclimatique de l’INRA et la base associée de données. Rapport CTPS Abricot, 54 p.

599

600

601

602Gleason, M.L., Duttweiler, K.B., Batzer, J.C., Taylor, S.E., Sentelhas, P.C., Monteiro, 603J.E.B.A., Gillespie, T.J., 2008. Obtaining weather data for input to crop disease-warning 604systems: leaf wetness duration as a case study. Scientia Agricola 65, 76-87. 605https://doi.org/10.1590/S0103-90162008000700013

606

607Gouache, D., Léon, M. S., Duyme, F., Braun, P., 2015. A novel solution to the variable 608selection problem in Window Pane approaches of plant pathogen - Climate models: 609Development, evaluation and application of a climatological model for brown rust of wheat. $\begin{array}{llllll}610 \text { Agricultural } & \text { and } & \text { Forest } & \text { Meteorology } & 205 & \text { pp. }\end{array}$

611http://dx.doi.org/10.1016/j.agrformet.2015.02.013

612

613Hack, H., Bleiholder, H., Buhr, L., Meier, U., Schnock-Fricke, U., Weber, E., Witzenberger, 614A., 1992. Einheitliche Codierung der phänologischen Entwicklungsstadien mono- und 615dikotyler Pflanzen - Erweiterte BBCH-Skala, AllgemeinNachrichtenbl. Deut. 616Pflanzenschutzd., 44 pp. 265-270.

617

618

619 
620Hrustić, J., Mihajlović, M., Grahovac, M., Delibašić, G., Bulajić, A., Krstić, B., Tanović, B., 6212012. Genus Monilinia on pome and stone fruit species. Pesticidi i fitomedicina 27, $283-297$.

622

623Jeschke, J.M., Strayer, D.L., 2008. Usefulness of Bioclimatic Models for Studying Climate 624Change and Invasive Species. Annals of the New York Academy of Sciences 1134, 1-24. 625https://doi.org/10.1196/annals.1439.002

626

627Jouzel, J., Déqué, M., Jouini, M., Planton, S., Vautard, R., 2014. Le climat de la France au 628XXIe siècle (No. 4). Ministère de l'Ecologie, du Développement durable et de l’Energie.

629

630Juroszek P, von Tiedemann A, 2015. Linking plant disease models to climate change scenarios 631to project future risks of crop diseases: a review. Journal of Plant Diseases and Protection 122, 6323-15.

633

634Koball, D.C., Wilcox, W.F., Seem, R.C., 1997. Influence of incubation-period humidity on the 635development of brown rot blossom blight of sour cherry. Phytopathology 87, 42-49.

636

637

638

639Lane, C.R., 2002. A synoptic key for differentiation of Monilinia fructicola, M. fructigena and 640M. laxa, based on examination of cultural characters. EPPO Bulletin 32, 489-493.

641

642Launay M, Caubel J, Bourgeois G, Huard F, Cortazar-Atauri IG, Bancal MO, Brisson N, 6432014. Climatic indicators for crop infection risk: Application to climate change impacts on 
644five major foliar diseases in Northern France. Agriculture, Ecosystems, and Environment 197, 645147-158.

646

647Leyronas, C., Nicot, P.C., 2013. Monitoring viable airborne inoculum of Botrytis cinerea in 648the South-East of France over 3 years: relation with climatic parameters and the origin of air 649masses. Aerobiologia 29. https://doi.org/10.1007/s10453-012-9280-0

650

651Lichou, J., Jay, M., 2012. Monographie abricot. CTIFL.

652

653Luo, Y., Morgan, D.P., Michailides, T.J., 2001. Risk analysis of brown rot blossom blight of 654prune caused by Monilinia fructicola. Phytopathology 91, 759-768.

655

656Magarey, R.D., Sutton, T.B., Thayer, C.L., 2005. A Simple Generic Infection Model for Foliar 657Fungal Plant Pathogens. Phytopathology 95, 92-100. https://doi.org/10.1094/PHYTO-956580092

659

660Maier, H.R., Guillaume, J.H.A., van Delden, H., Ridell, G.A., Haasnoot, M., Kwakkel, J.H., 6612016. An uncertain future, deep uncertainty, scenarios, robustness and adaptation: How do 662they fit together? Environmental Modelling \& Software 81, 154-164. 663https://doi.org/10.1016/j.envsoft.2016.03.014

664

665Morales G., Moragrena, C., Montesinos, E., Llorente, I., 2018. Environmental and inoculum 666effects on epidemiology of bacterial spot disease of stone fruits and development of a disease 667forecasting system. Eur J Plant Oathol 152 pp. 635-651. https://doi.org/10.1007/s10658-018$6681507-7$ 
670

671

672

673

674Oliveira Lino, L., Pacheco, I., Mercier, V., Faoro, F., Bassi, D., Bornard, I., Quilot-Turion, B., 6752016. Brown Rot Strikes Prunus Fruit: An Ancient Fight Almost Always Lost. Journal of 676Agricultural and Food Chemistry 64, 4029-4047. https://doi.org/10.1021/acs.jafc.6b00104 677

678Pachauri, R.K., Meyer, L., Equipe de rédaction principale, 2014. IPCC, 2014: Climate Change 6792014: Synthesis Report. Contribution of Working Groups I, II and III to the Fifth Assessment 680Report of the Intergovernmental Panel on Climate Change (No. 5). GIEC, Genève.

681

682Parveau, C.-É., Gomez, C., Mercier, V., Brun, L., Guillermin, A., Clauzel, G., Broquaire, J.683M., Audergon, J.-M., 2016. Guide des sensibilités variétales aux bio-agresseurs - Fiche n³ : 684Monilioses sur fleur. L’Arboriculture Fruitière 5.

685

686

687

688

689

690

691

692

693 
694

695

696Tamm, L., Minder, C.E., Flückiger, W., 1995. Phenological analysis of brown rot blossom 697blight of sweet cherry caused by Monilinia laxa. Phytopathology 85, 401-408.

698

699Trebicki P, Finlay K, 2019. Pests and diseases under climate change; it's threats to food 700security, 229-248. In: Yadav et al (eds). Food Security and Climate Change. Wiley Blackwell. 701

702Willmott, C.J., 1981. ON THE VALIDATION OF MODELS. Physical Geography 2, 184703194. https://doi.org/10.1080/02723646.1981.10642213

704 
Fig.1: Localisation of the grids studied and their associated clusters (Best viewed in colour).

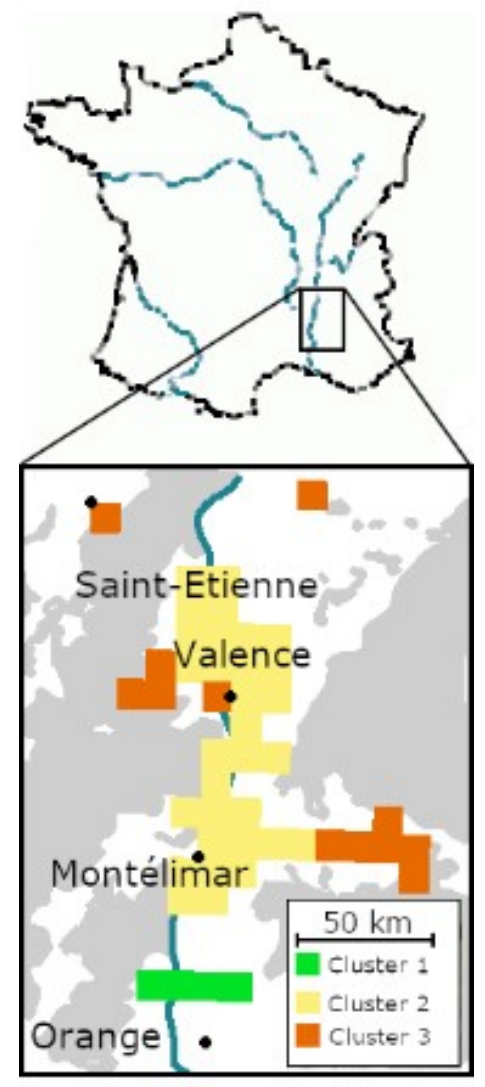


Fig. 2: Method used to calculate climate change for a given year $n$ and cultivar. (1) Computations for year $n$ start on the $15^{\text {th }}$ of October of year $n-1$. For the dormancy model, it is assumed that the cold needs of apricot have not started to be fulfilled prior to this date. (2) Phenological models compute the F50 date given the daily average temperature. (3) The expand of the blooming period around F50 is estimated given the distribution of disease-sensitive stages. (4) Daily rainfall and temperature during the blooming period are extracted and (5) CIB is calculated for year $n$




Fig 3: Simulated vs. Observed values for blossom blight incidence (I, dimensionless). $R^{2}=0.941$, Intercept $=0.009 ;$ slope $=0.935$.

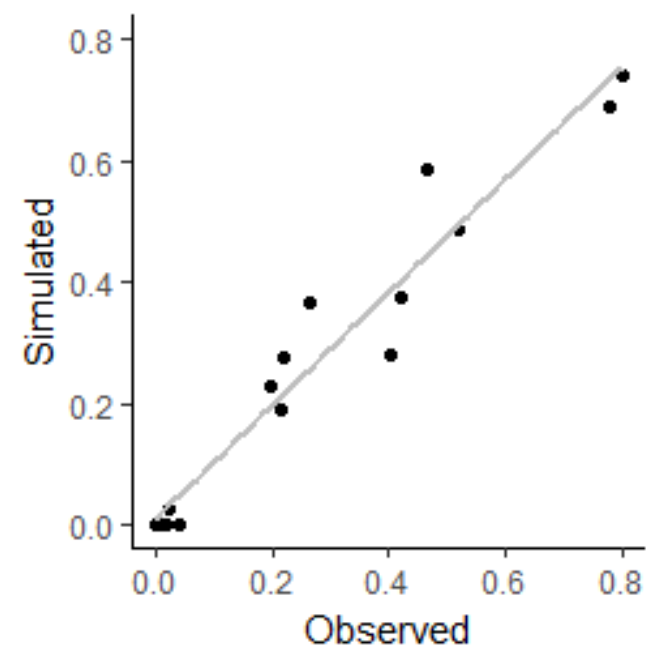


Fig 4: 3D representation of our model as a surface response of blossom blight incidence to rainfall (mm) and temperature $\left({ }^{\circ} \mathrm{C}\right.$ ) (left) and residuals associated with each point of the dataset as a function of rainfall and temperature (right). The size of each point represents the value of the residual and the colour the sign of the residual. Lines correspond to different predicted levels of incidence.
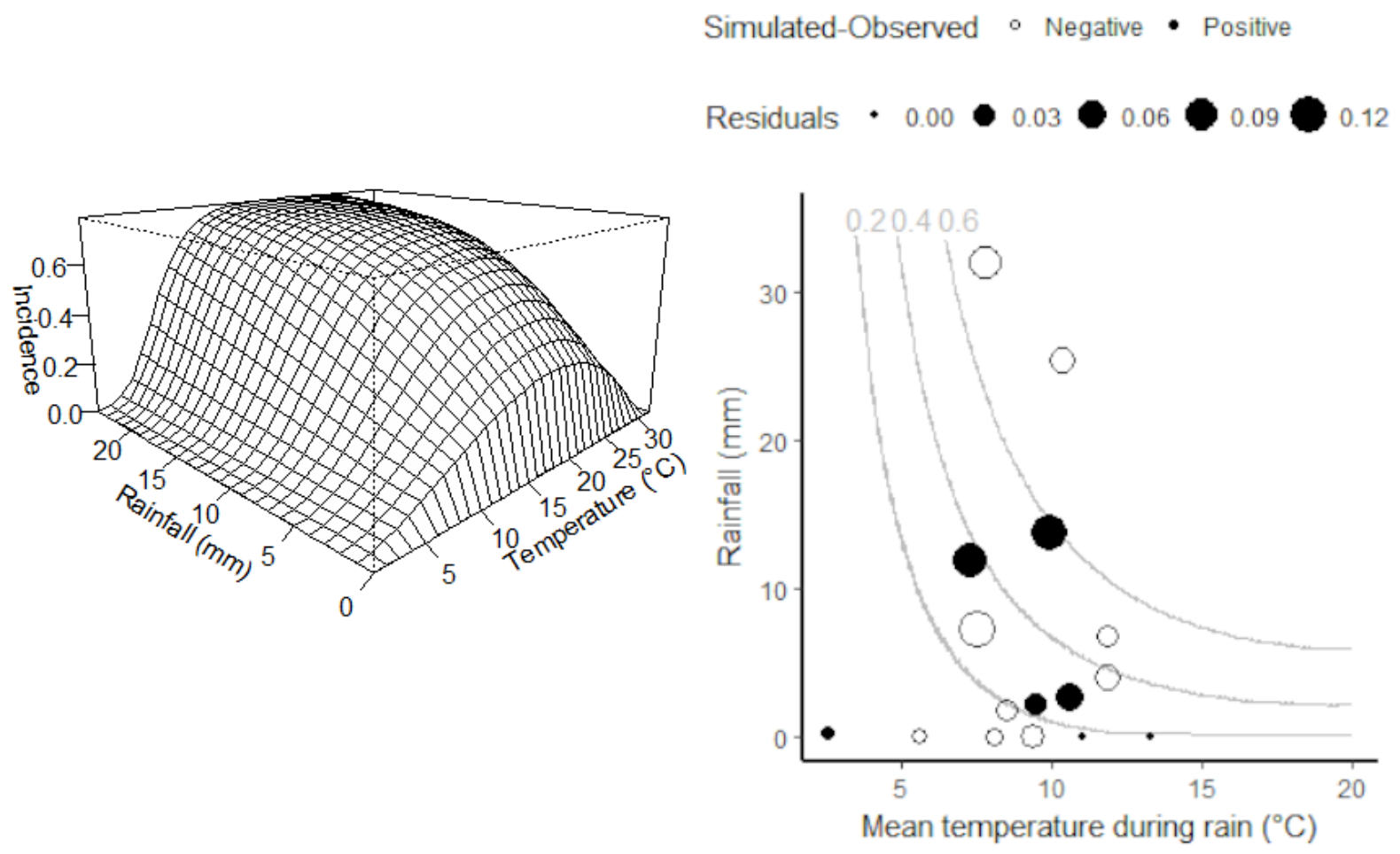
Fig 5: Predicted Climatic Index of cumulated Blight risk (CIB, cumulated \%) versus observed Twig Blight Incidence (TBI, dimensionless).

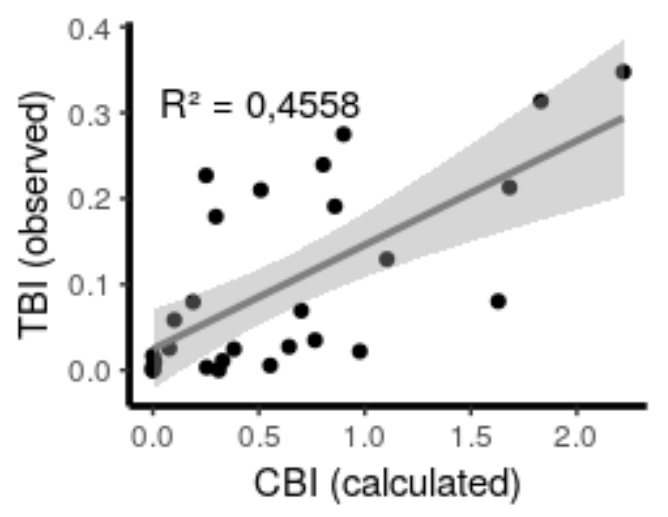


Fig 6: Evolution of the mid-blooming date (DOY) for the different cultivars and clusters under scenario RCP8.5. Linear regression lines are shown for clarity.

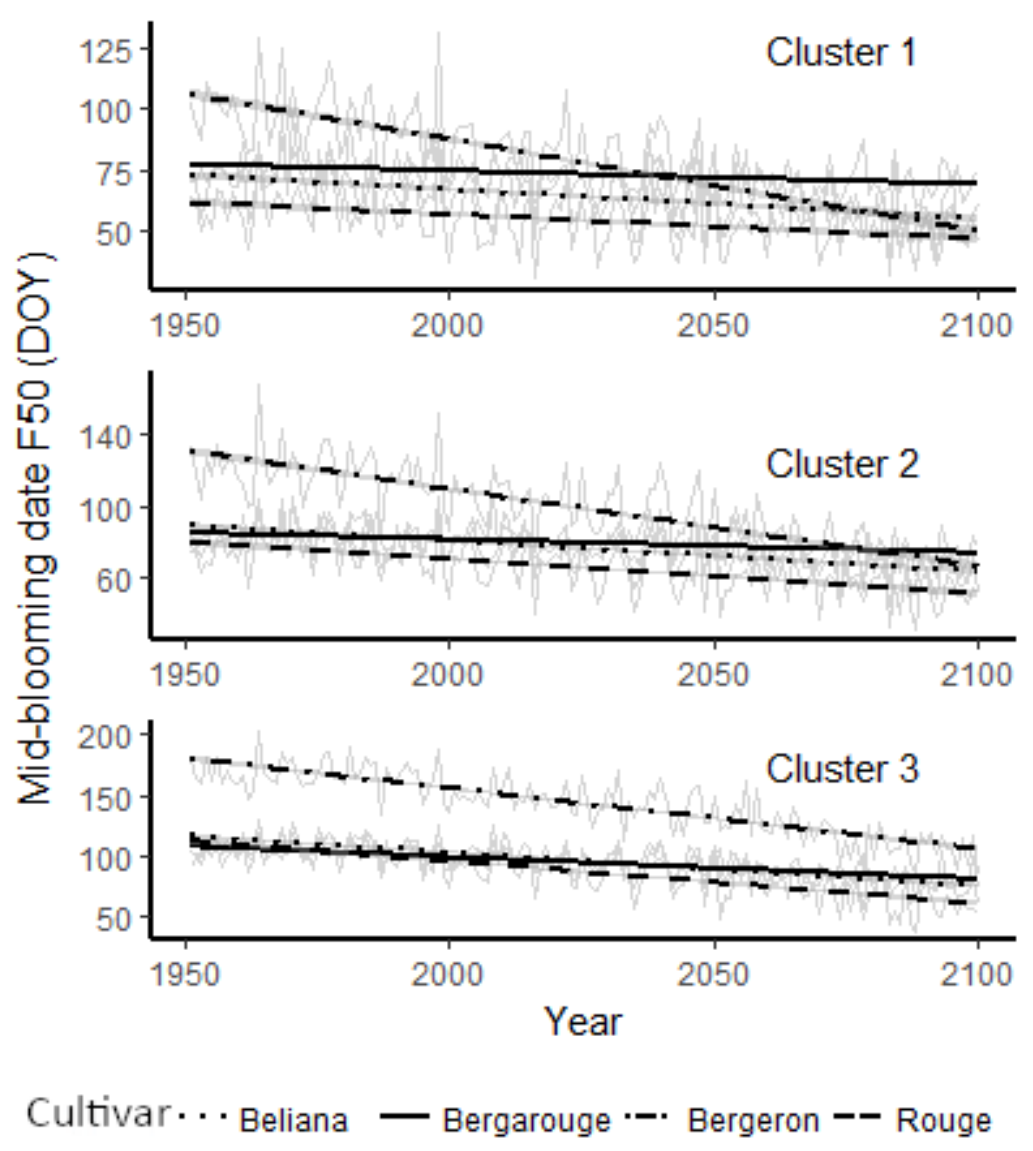


Fig 7: Mean temperature $\left({ }^{\circ} \mathrm{C}\right)$ and mean cumulated rainfall (mm) experienced during blooming for the different cultivars and clusters. The start of the line represents the situation during the [19701999] period and the head of the arrow the situation forecasted for the [2070-2099] period.

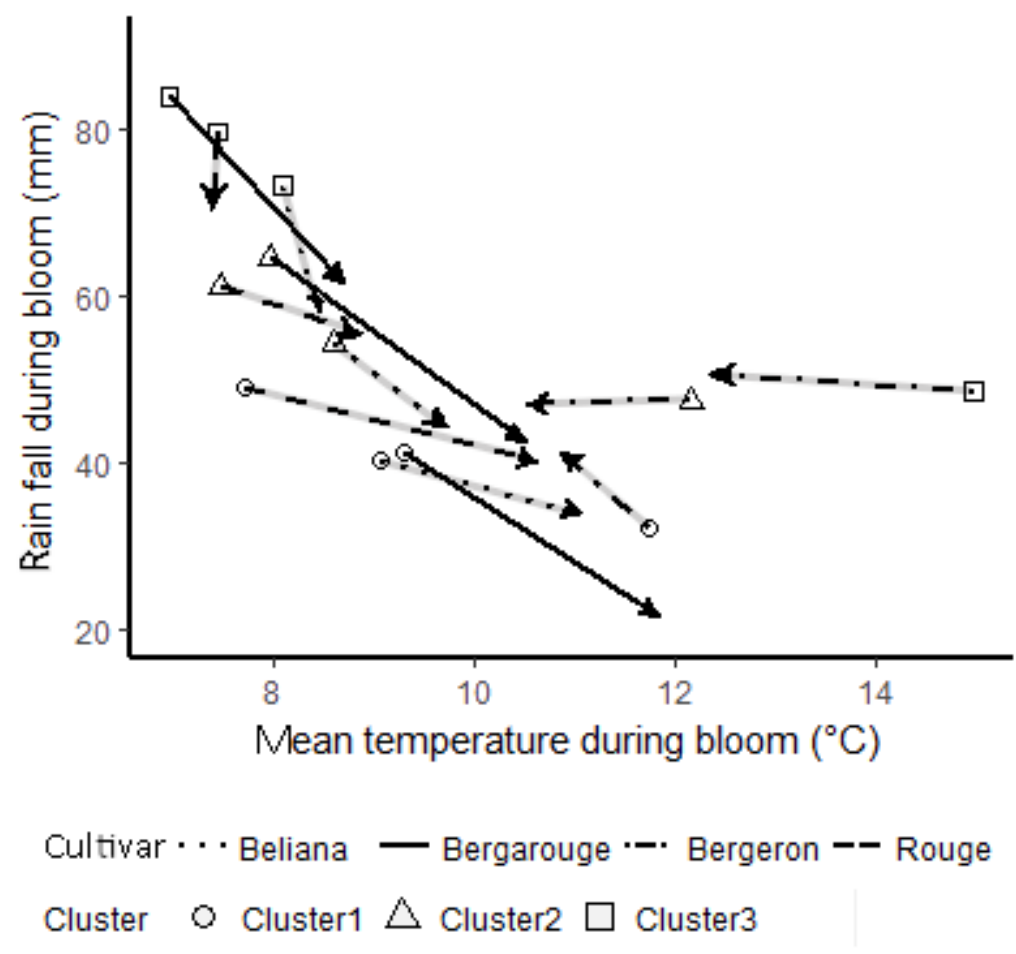


Fig 8: Mean simulated CIB ( \pm one standard deviation) by period (p: past, nf: near future, pf: far future) for each cluster and cultivar under RCP 8.5. The colours are red for a significant increase in the risk and green for a significant reduction in the risk. Letters are the result of the Kruskall-Wallis comparison between periods within one Cultivar-Cluster panel (best viewed in colour).
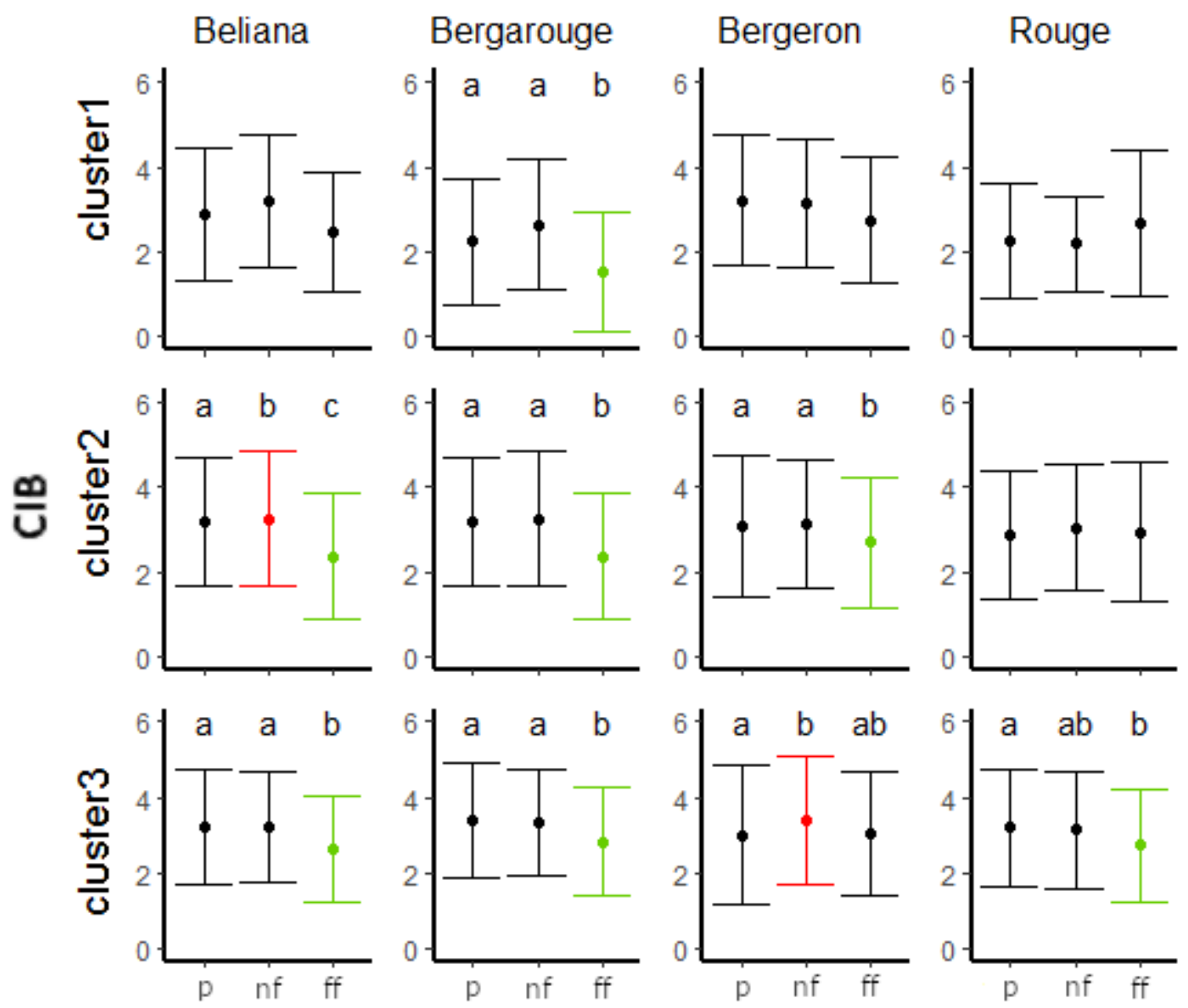
Table.1: Parameter values of the fitted model. Bolt parameters were chosen priori to optimisation according to the method described by Tamm et al. 1995

\begin{tabular}{|l|l|}
\hline Parameter & Value \\
\hline $\mathbf{T}_{\text {min }}$ & 0 \\
\hline $\mathbf{T}_{\max }$ & 31 \\
\hline $\mathrm{E}$ & 0.029 \\
\hline $\mathbf{i}_{\mathbf{m a x}}$ & 0.79 \\
\hline $\mathbf{m}$ & 0.9 \\
\hline$\rho_{1}$ & 1.575 \\
\hline$\rho_{2}$ & 1.965 \\
\hline$\gamma_{1}$ & 1.709 \\
\hline$\gamma_{2}$ & 1.472 \\
\hline
\end{tabular}

